\title{
EFFECT OF NEUROMODULATION ON NEUROTROPHIC FACTORS IN PATIENTS WITH CHRONIC DISORDERS OF CONCIOUSNESS
}

lazeva EG $\bowtie$, Legostaeva LA, Bakulin IS, Poydasheva AG, Abaimov DA, Suponeva NA, Shabalina AA, Ryabinkina YV, Piradov MA

Research Center of Neurology, Moscow, Russia

Transcranial magnetic stimulation (TMS) is one of rehabilitation approaches for patients with chronic disorders of consciousness (DOC). The aim of our study was to assess neurotrophic factors and the changes of those after TMS course in patients with chronic DOC. We enrolled 26 patients with chronic DOC of various etiology and 21 heathy volunteers. Blood serum and cerebrospinal fluid (CSF) were collected from all patients before and after the TMS course, the levels of BDNF, NSE, NGF, PDGF, GDNF and NT3 were assessed in the biomaterial. The blood BDNF, NSE, PDGF, GDNF and NT3 in patients with chronic DOC were higher compared to healthy volunteers $(p<0.05)$. We found no correlations between the type of DOC and neurotrophic factors concentrations in blood and CSF. The CSF level of BDNF in patients after traumatic brain injury (TBI) was higher compared to patients with non-traumatic chronic DOC $(p<0.05)$. We also found the increase of CSF BDNF after the TMS course in patients after TBI $(p<0.05)$. No other significant differences between groups and another blood and cerebrospinal fluid biomarker levels were detected. Thus, the serum BDNF, NSE, PDGF, GDNF and NT3 levels in patients with chronic DOC were higher compared to healthy volunteers. The BDNF level in CSF was higher in patients with traumatic DOC, and it also increased after the course of high-frequency TMS in this group. This fact may indicate the long-term neuronal plasticity processes in patients after TBI, as well as more favorable rehabilitation prognosis.

Keywords: disorders of consciousness, vegetative state, unresponsive wakefulness syndrome, minimally consciousness state, BDNF, NSE, PDGF, NT3, neurotrophic factors, transcranial magnetic stimulation

Funding: the study was supported by Russian Science Foundation (RSF) grant 16-15-00274.

Author contribution: lazeva EG — clinical practice, clinical assessment, collecting biomaterials, manuscript writing; Legostaeva LA — clinical practice, clinical assessment, collecting biomaterials; Bakulin IS, Poydasheva AG — PTMC, manuscript writing; Abaimov DA, Shabalina AA — laboratory tests; Suponeva NA, Ryabinkina YV, Piradov MA — study planning and management.

Compliance with ethical standards: the study was approved by the Ethics Committee of the Research Center of Neurology (protocol No. 9-5.16 dated October 26, 2016). Patients were included in the study after obtaining the informed consent from their legal representatives.

$\triangle$ Correspondence should be addressed: Elizaveta G. lazeva

Volokolamskoye shosse, 80, Moscow, 125367; yazeva@neurology.ru

Received: 19.08.2020 Accepted: 05.09.2020 Published online: 23.09.2020

DOI: $10.24075 /$ brsmu.2020.056

\section{ВЛИЯНИЕ КУРСА НЕЙРОМОДУЛЯЦИИ НА ПРОФИЛЬ НЕЙРОТРОФИЧЕСКИХ ФАКТОРОВ У ПАЦИЕНТОВ С ХРОНИЧЕСКИМИ НАРУШЕНИЯМИ СОЗНАНИЯ}

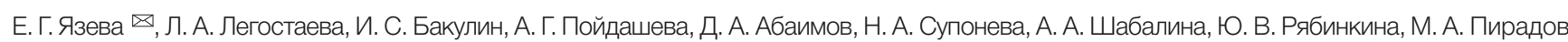
Научный центр неврологии, Москва, Россия

Одним из методов реабилитации пациентов с хроническим нарушением сознания (ХНС) является транскраниальная магнитная стимуляция (ТМС). Целью работы было изучить нейротрофические факторы у пациентов с ХНС и их изменение на фоне применения курса ТМС. Пациентам с ХНС различной этиологии в хронических сроках (26 человек) и здоровым добровольцам (21 человек) проводили курс ритмической ТМС левой ангулярной извилины. У всех участников собирали образцы сыворотки крови и ликвора до и после курса. В биоматериале исследовали уровни BDNF, NSE, NGF, PDGF, GDNF, NT3. Показано, что уровни BDNF, NSE, PDGF, GDNF, NT3 в крови у пациентов с ХНС выше, чем у здоровых добровольцев ( $<$ 0,05). Не выявлено различий в концентрации нейротрофических факторов в крови и ликворе в зависимости от формы ХНС. У пациентов с последствиями черепномозговой травмы уровень BDNF в ликворе оказался выше, чем у пациентов с нетравматической этиологией XНС (p < 0,05). После проведения курса ТМС показано увеличение уровня BDNF в ликворе у постравматических пациентов ( $p<0,05)$. Других значимых изменений по группам и другим биомаркерам в крови и ликворе выявлено не было. Таким образом, уровни нейротрофических факторов BDNF, NSE, PDGF, GDNF, NT3 в сыворотке крови пациентов с XHC выше, чем у здоровых добровольцев. Уровень BDNF в ликворе пациентов был выше при постравматическом ХНС и увеличивался после проведения курса высокочастотной ТМС у этой группы. Это может свидетельствовать о длительных процессах нейропластичности, происходящих у пациентов после черепно-мозговой травмы, и более благоприятном реабилитационном прогнозе.

Ключевые слова: хронические нарушения сознания, вегетативное состояние, синдром ареактивного бодрствования, состояние минимального сознания, BDNF, NSE, PDGF, NT3, нейротрофические факторы, транскраниальная магнитная стимуляция

Финансирование: работа выполнена при поддержке гранта Российского научного фонда (РНФ) 16-15-00274.

Вклад авторов: Е. Г. Язева - клиническая работа, клиническая оценка, сбор биоматериалов, подготовка рукописи; Л. А. Легостаева - клиническая работа, клиническая оценка, сбор биоматериалов; И. С. Бакулин, А. Г. Пойдашева - выполнение рТМС, подготовка рукописи; Д. А. Абаимов, А. А. Шабалина - выполнение лабораторных исследований; Н. А. Супонева, Ю. В. Рябинкина, М. А. Пирадов - планирование и руководство исследованием.

Соблюдение этических стандартов: исследование одобрено этическим комитетом Научного центра неврологии (протокол № 9-5.16 от 26 октября 2016 г.) Пациентов включали в исследование после получения от их родственников добровольного письменного информированного согласия.

$\bigotimes$ Для корреспонденции: Елизавета Григорьевна Язева Волоколамское шоссе, д. 80, г. Москва, 125367; yazeva@neurology.ru

Статья получена: 19.08.2020 Статья принята к печати: 05.09.2020 Опубликована онлайн: 23.09.2020

DOI: $10.24075 /$ vrgmu.2020.056 
Advancements in intensive care led to increased number of patients who survived severe brain injury and numerous disabled patients with chronic disorders of consciousness (DOC) including the vegetative state (VS), also known as unresponsive wakefulness syndrome (UWS), the minimally conscious state (MCS) and the emergence from MCS (eMCS). As is well known, the spontaneous opening of eyes with no signs of self- or environmental awareness is typical for VS. MCS is distinguished by minimal but clearly discernible evidence of awareness [1-4]. Patients with chronic DOC pose many significant challenges for health professionals and society, such as development of approaches to social adaptation of patients, and search for rehabilitation methods with proven effectiveness. That creates a large field for clinical and fundamental neuroscientific research.

Currently, most studies of chronic DOC are focused on neurophysiolocal and neuroimaging features of the impaired consciousness, as well as on implementation of various methods for the consciousness level improvement. Of those, the noninvasive neuromodulation techniques attract most attention, such as transcranial magnetic stimulation (TMS) and transcranial direct current stimulation (tDCS) [5]. However, the study of biochemical changes in the nervous tissue is relegated to the background. To date, a large number of neurotrophic factors are known. The factors are involved in the central nervous system (CNS) functional regeneration, and may be used as neuronal plasticity markers.

In the context of chronic DOC and recovery of consciousness the brain-derived neurotrophic factor (BDNF) is of particular interest. It is known as one of the most active neuroprotective factors, and is involved in regeneration of neurons both during the acute phase of brain tissue damage and in chronic one [6]. Among other neurotrophins involved in neural plasticity process are neurotrophin-3 (NT3), glial cell derived neurotrophic factor (GDNF), platelet derived growth factor (PDGF), and nerve growth factor (NGF). Neurotrophic factors are generally studied in the context of search for possible neurodegenerative diseases treatment methods [6], however, the experience of using them for treatment of injuries to nervous tissue had been also reported [7]. NT3 is known mainly as a factor responsible for stimulation of fetal neurogenesis. It is involved in generation of neurons from stem cells and in regeneration of neurons in adults [8]. GDNF increases the survival rate of dopaminergic and motor neurons, therefore, it is also considered a factor promoting the nervous tissue repair [9]. PDGF is best known for its effect on angiogenesis and mesenchymal stem cells. Furthermore, PDGF stimulates glial cells (oligodendrocytes, for instance), which affects the neurons functioning and regeneration [10]. NGF stimulates growth and repair of neurons [6]. Another potentially interesting protein is the marker of neuronal injury, the neuron specific enolase (NSE). NSE is commonly studied in the context of acute conditions (acute traumatic brain injury, cardiac arrest). It shows the prognostic value during the acute brain injury both for subsequent consciousness recovery and brain death [11, 12].

Very few studies so far assessed neurotrophic factors in patients with chronic DOC, and their potential role in the recovery of consciousness remains unknown. As previously mentioned, one of the major approaches to rehabilitation of such patients is the noninvasive brain stimulation, particularly TMS. A number of papers report the changes of plasma BDNF, NT3, GDNF and PDGF levels in patients after TMS, which might be interesting in terms of studying the damaged nervous tissue repair mechanisms [13-15].

Currently, the prognostic value of biochemical markers for chronic DOC generally remains understudied, as well as their correlations with repair processes. The study was aimed to assess the neurotrophic factors levels in blood and cerebrospinal fluid (CSF) of patients with chronic DOC and their change during the course of repetitive TMS (rTMS).

\section{METHODS}

Inclusion criteria were: age over 18 years; chronic DOC (vegetative state or minimally conscious state); within a period of more than 3 months for non-traumatic brain injury or more than 12 months after traumatic brain injury (TBI); traumatic and non-traumatic etiology (after hypoxia, CNS infections, stroke, etc.); stable condition of the patient; no current infectious complications, disfunctions of organs and systems; no contraindications of rTMS. We performed routine EEG to ensure the safety of rTMS in patients with organic lesions of the CNS [16]. Exclusion criteria: patients with epileptiform discharges on EEG screening were excluded.

Patients after admission were examined with the validated Russian version of the Coma Recovery Scale - Revised (CRS-R) score [17], then we conducted venipuncture for blood sampling and lumbar puncture in accordance with standard protocol for CSF sampling. After that we delivered the highfrequency rTMS protocol over the left angular gyrus [18]. The patient's rehabilitation also included standard procedures, such as physical exercises, massage therapy and verticalization. After the rTMS course the patients were assessed with the CRS-R score again. The second sampling of serum and CSF was performed within 24 hours after the last rTMS session.

After sampling of biomaterials, blood was subjected to centrifugation in order to obtain serum. The serum and CSF samples were subsequently frozen at $-71^{\circ} \mathrm{C}$. The levels of BDNF, NSE, NGF, PDGF, GDNF, NT3 were evaluated. Detection and quantification were performed by sandwich enzyme linked immunosorbent assay (ELISA). The R\&D Systems (USA, China) and Vector-Best (Russia) reagent kits were used. The calibrators provided by the reagent manufacturers were used in all studies. The duplicate readings were performed with VICTOR 2 system (PerkinEImer; USA) using the lyophilized control serum/plasma samples with low and high values of studied parameters.

The control group included healthy volunteers, from whom serum samples were obtained.

Statistical analysis was carried out by means of the SPSS Statistics v23 software. We performed the biomarker levels intergroup comparisons using the Mann-Whitney U-test. We tested differences between boimarkers' levels before and after the rTMS course using the Wilcoxon signed-rank test (the differences between groups were accepted when $p<0.05$ ). Quantitative data were reported as median, lower and upper quartiles (Me [LQ, UQ]).

\section{RESULTS}

We enrolled 26 patients and 21 healthy volunteers. The surveyed patients' demographics and structure of diagnosis are listed in Table 1. The sex ratio in the group of healthy volunteers (M/F) was $8 / 13$, and the average age was 30 [27; $36]$ years. We didn't find significant gender and age differences between healthy volunteers and the patients.

The blood and CSF analysis results are listed in Tables 2 and 3. The levels of BDNF, NSE, PDGF, GDNF, and NT3 in serum were significantly higher in patients with chronic DOC, than in healthy volunteers, but there were no differences in NGF levels.

We didn't find any differences in serum BDNF, NSE, NGF, PDGF, GDNF, NT3 both between groups of patients with VS/ UVS and MCS, and due to DOC etiology. 
Table 1. Baseline characteristics of patients included in the study of biochemical markers in chronic DOC

\begin{tabular}{|l|c|c|c|c|c|c|c|}
\hline \multirow{2}{*}{ Parameter } & \multirow{2}{*}{ Total DOC } & \multicolumn{3}{c|}{ Type of DOC } & \multicolumn{3}{c|}{ DOC Etiology } \\
\cline { 3 - 8 } & & VS/UWS & MCS & $p$ & TBI & Non-traum. & $p$ \\
\hline Type of DOC (VS/ MCS) & 26 & 14 & 12 & & 10 & 16 & 0.02 \\
\hline Age, yr. & $27[23 ; 41]$ & $25[23 ; 33]$ & $29[24 ; 44]$ & 0.86 & $24[21 ; 25]$ & $33[25 ; 47]$ & 0.01 \\
\hline Sex (M/F) & $16 / 10$ & $7 / 7$ & $9 / 3$ & 0.05 & $7 / 3$ & $7 / 7$ & 0.18 \\
\hline Etiology (TBI/non-traum.) & $10 / 16$ & $3 / 11$ & $7 / 5$ & 0.06 & 10 & 16 & \\
\hline Time postinjury, months & $12[8 ; 22]$ & $12[8 ; 19]$ & $14[9 ; 23]$ & 0.63 & $14[12 ; 21]$ & $12[7 ; 22]$ & 0.7 \\
\hline CRS-R score before rTMS & $7[6 ; 11.75]$ & $6[6.6]$ & $13[10 ; 17]$ & $<0.01$ & $12[7 ; 15]$ & $6[6.9]$ & 0.03 \\
\hline
\end{tabular}

Note: VS — vegetative state; non-traum. — non-traumatic; MCS — minimally conscious state; DOC — chronic disorder of consciousness; TBI — traumatic brain injury.

We detected significantly higher level of CSF BDNF in patients after $\mathrm{TBI}$ compared to patients with non-traumatic DOC. There were no differences in other studied markers CSF levels between groups.

We analysed the biomarker levels in blood and CSF before and after the rTMS course. It was possible to obtain CSF samples before and after rTMS only in 21 people. Withdrawal of the informed consent by relatives, the refusal of the second lumbar puncture, or inability to complete the rTMS protocol were the reasons to get less samples. There were $11 \mathrm{VS} / \mathrm{UVS}$ patients and 10 MCS patients in rTMS group. Eight patients had traumatic etiology of DOC, and in 13 ones had the nontraumatic etiology. Comparison of CRS-R scores before TMS course in the groups due to the chronic DOC type (VS/UWS or MCS) and etiology didn't show any differences. The patients after $\mathrm{TBI}$ were significantly younger than ones with nontraumatic etiology. There were no other significant differences between the groups.

We didn't find any significant changes of biomarker levels in serum and CSF after rTMS application in the whole group, in VS/UWS and MCS patients distinctly, traumatic and nontraumatic DOC. The only difference was in BDNF level: we saw the significant increase of CSF BDNF level after rTMS course in patients with TBI (see Figure).

The level of consciousness in MCS patients improved after the rTMS course: their CRS-R score increased by 2.1 points on average regardless of etiology, at the same time, the VS/ UWS patients didn't show any changes (the clinical results are reported in the paper [18]). We didn't find any correlations in biomarker levels before rTMS course and patients' improvement via CRS-R score after the course.

Thus, we found that the CSF BDNF level is significantly higher in patients with posttraumatic chronic DOC compared to non-traumatic chronic DOC, and it was increasing after the rTMS course in that group. There were no differences in concentrations of other studied biomarkers (NSE, NGF, PDGF, GDNF $и$ NT3) in CSF and serum, both between groups of patients and after the rTMS course.

\section{DISCUSSION}

The study of biochemical markers injury and repair of the central nervous system may contribute to a deeper understanding of appropriate patterns.

In our study we measured the levels of BDNF, NSE, NGF, PDGF, GDNF, and NT3. In patients with traumatic chronic DOC the concentration of BDNF in CSF was significantly higher compared to patients with non-traumatic DOC, and the concentration increased after the rTMS course in the discussed group. When comparing the factors' blood levels in patients and healthy volunteers, it turned out that the levels of all factors except NGF were significantly higher in the patients,

Table 2. Serum biomarkers levels in patients with chronic DOC and healthy volunteers

\begin{tabular}{|l|c|c|c|c|c|c|c|c|c|}
\hline \multirow{2}{*}{ Biomarker } & \multicolumn{3}{|c|}{ Total group } & \multicolumn{3}{|c|}{ Type of DOC } & \multicolumn{3}{c|}{ DOC Etiology } \\
\cline { 2 - 10 } & DOC, $n=26$ & Healthy, $n=21$ & $p$ & VS/UWS, $n=14$ & MCS, $n=12$ & $p$ & TBI, $n=10$ & Non-traum., $n=16$ & $p$ \\
\hline BDNF, pg/ml & $770[640 ; 950]$ & $54[40 ; 62]$ & $<0.01$ & $800[510 ; 1010]$ & $770[675 ; 915]$ & 1 & $750[645 ; 875]$ & $820[560 ; 980]$ & 0.9 \\
\hline NSE, $\mathrm{ng} / \mathrm{ml}$ & $53[30 ; 64]$ & $10[9 ; 13]$ & $<0.01$ & $40[28 ; 54]$ & $61[51 ; 71]$ & 0.13 & $55[30 ; 63]$ & $52[30 ; 62]$ & 0.86 \\
\hline NGF, pg/ml & $222[145 ; 267]$ & $128[103 ; 211]$ & 0.54 & $219[103 ; 261]$ & $229[184 ; 282]$ & 0.35 & $229[186 ; 260]$ & $219[144 ; 313]$ & 1 \\
\hline PDGF, pg/ml & $223[200 ; 267]$ & $72[64 ; 90]$ & $<0.01$ & $243[191 ; 282]$ & $213[200 ; 246]$ & 0.86 & $205[200 ; 239]$ & $235[198 ; 289]$ & 0.45 \\
\hline GDNF, pg/ml & $5.3[3.7 ; 6.4]$ & $1.1[1 ; 1.5]$ & $<0.01$ & $4.6[3.6 ; 5.7]$ & $5.8[4.1 ; 6.5]$ & 0.3 & $5.8[4.5 ; 6.4]$ & $4.6[3.6 ; 5.9]$ & 0.39 \\
\hline NT 3, pg/ml & $365[329 ; 504]$ & $89[69 ; 103]$ & $<0.01$ & $360[322 ; 472]$ & $388[356 ; 518]$ & 0.43 & $388[332 ; 524]$ & $362[339 ; 491]$ & 0.78 \\
\hline
\end{tabular}

Note: VS — vegetative state; non-traum. — non-traumatic; MCS — minimally conscious state; DOC — chronic disorder of consciousness; TBI — traumatic brain injury. Table 3. Cerebrospinal fluid biomarkers levels in patients with chronic DOC

\begin{tabular}{|c|c|c|c|c|c|c|c|}
\hline \multirow{2}{*}{ Biomarker } & \multirow{2}{*}{$\begin{array}{c}\text { Total DOC group, } \\
\qquad n=26\end{array}$} & \multicolumn{3}{|c|}{ Type of DOC } & \multicolumn{3}{|c|}{ DOC Etiology } \\
\hline & & VS/UWS, $n=14$ & MCS, $n=12$ & $p$ & TBI, $n=10$ & Non-traum., $n=16$ & $p$ \\
\hline BDNF, ng/ml & $18[11 ; 30]$ & $14[11 ; 31]$ & $21[12 ; 27]$ & 0.49 & $28[21 ; 38]$ & $13[11 ; 20]$ & 0.04 \\
\hline $\mathrm{NSE}, \mathrm{ng} / \mathrm{ml}$ & $96[81 ; 131]$ & $95[78 ; 104]$ & $98[90 ; 156]$ & 0.27 & $110[94 ; 154]$ & $95[79 ; 101]$ & 0.2 \\
\hline $\mathrm{NGF}, \mathrm{ng} / \mathrm{ml}$ & $178[137 ; 233]$ & $178[120 ; 210]$ & $189[143 ; 242]$ & 0.53 & $177[137 ; 233]$ & $178[144 ; 219]$ & 0.82 \\
\hline GDNF, pg/ml & $170[135 ; 250]$ & $160[135 ; 240]$ & $193[140 ; 258]$ & 0.56 & $235[158 ; 261]$ & $145[123 ; 215]$ & 0.17 \\
\hline NT $3, \mathrm{ng} / \mathrm{ml}$ & $163[111 ; 215]$ & $145[110 ; 199]$ & $195[145 ; 240]$ & 0.19 & $195[128 ; 219]$ & $153[110 ; 211]$ & 0.34 \\
\hline
\end{tabular}

Note: VS — vegetative state; non-traum. — non-traumatic; MCS — minimally conscious state; DOC — chronic disorder of consciousness; TBI — traumatic brain injury. 


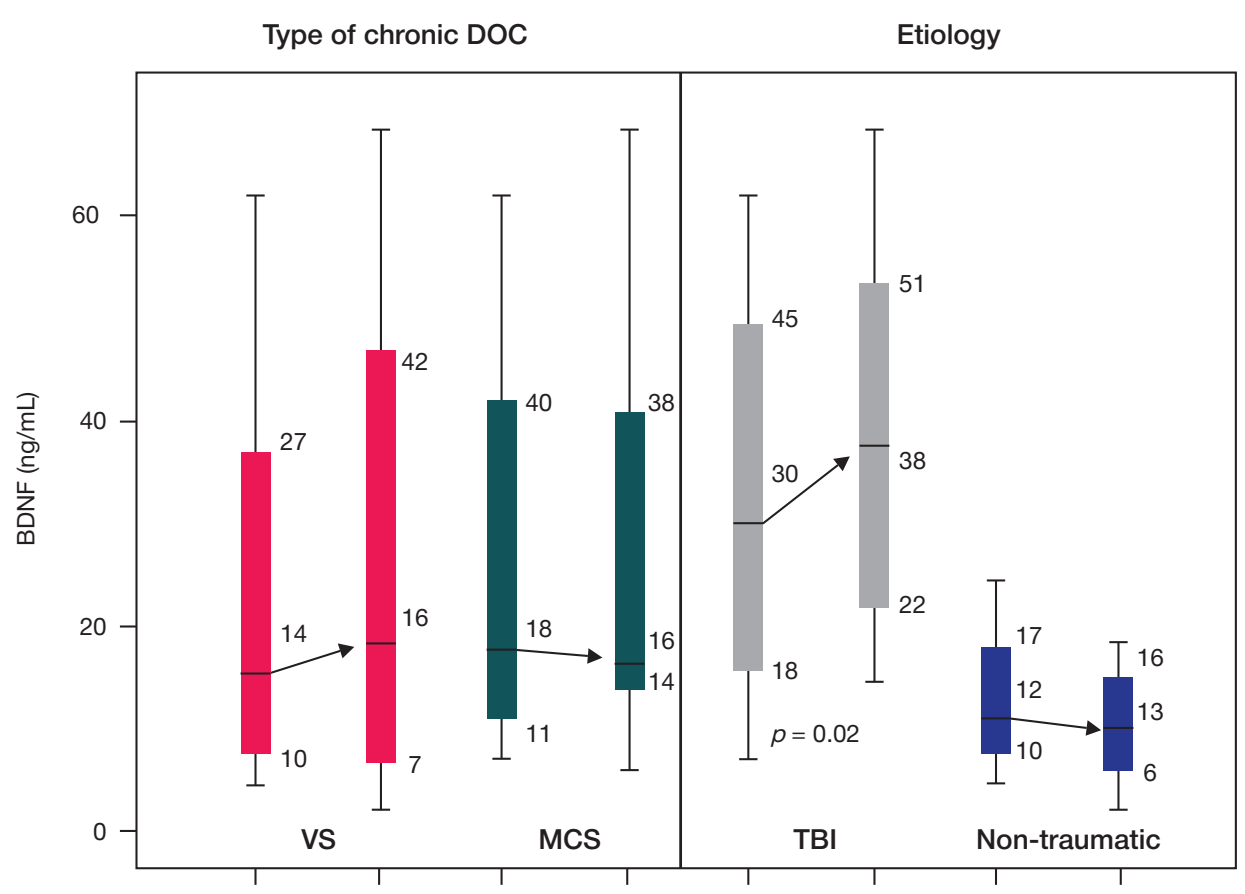

Figure. Change of BDNF levels in the cerebrospinal fluid of patients with chronic DOC after the course of rTMS by groups according to DOC type and etiology. VS vegetative state; MCS — minimally conscious state; DOC — disorder of consciousness; TBI — traumatic brain injury

which indicated the long-existing nervous tissue damage and ongoing repair processes.

In this context it should be understood that the synthesis and level of neurotrophins in patients with severe CNS injury is likely to be affected by the cause of the disorder, its duration, and the patient's age. Thus, it is difficult enough to obtain homogeneous results in the heterogenous group of patients with chronic DOC. It can be assumed however that the overall brain injury and nervous tissue repair process are similar in all patients with chronic DOC.

It is well known that in the nervous system neurotrophins are involved in the neurons survival and regeneration process [6], therefore, in patients with severe nervous system injury the elevated levels of neurotrophins are observed. This may be due to damaged blood-brain barrier, and suggests that neurotrophins may have a neuroprotective role [19-21]. During the analysis of patients by groups we detected significant differences in the CSF BDNF concentration. There were no significant differences in the other factors concentrations between patients with VS/UWS and MCS, traumatic and nontraumatic etiology, before and after rTMS course.

The role of BDNF as a neuroprotective factor promoting the nervous tissue repair is widely discussed in literature. Thus, its role in the spinal cord injury recovery is being actively studied, the elevated BDNF level after traumatic injury is reported [22, 23]. During the experiments on rats the researchers tried to repair the spinal cord by delivery of BDNF to the affected area [7]. The BDNF level increased proportional to severity of paresis after stroke [21]; the other study reported elevated BDNF after moderate TBI proportional to neurologic deficit [19]. Interesting data were reported on critically ill patients without brain injury: there were no correlations between elevated BDNF and other neurotrophins, as in our study [24]. The authors concluded that the discussed marker correlated with the patients' mortality. In another study with patients after TBI, the autors made the opposite conclusion: they didn't detect any correlation between the injury severity and the level of BDNF [25].

Thus, literature contains contradictory information on the role of BDNF and the changes of its concentration in various disorders. Unlike any other authors, we revealed the changes in the concentration of this factor in the CSF, but not in the blood serum. This fact may indicate that our chronic patients have already recovered the blood-brain barrier, but the neural plasticity processes still go on. The interesting fact is that the most active changes are seen in patients with TBI. This may be due to various factors. Firstly, the trauma patients have longer recovery period, therefore, the disorder of consciousness is considered persistent after 12 months in patients with TBI and after 3 months in patients with non-traumatic DOC [3]. Secondly, it is known that such patients have more favourable prognosis compared to patients with hypoxia [26]. Therefore, we can assume that recovery process is more active and lasts longer, that is what our results may indirectly indicate. It should be noted that among patients with TBI there were three people with VS/UWS and eight people with MCS. At first glance, it is reasonable to assume that elevated BDNF and the associated recovery processes were detected in the group with $\mathrm{TBI}$ due to higher proportion of patients with MCS. However, the comparison of groups with VS/UWS and MCS revealed no differences in the BDNF concentration. It can therefore be concluded that elevated CSF BDNF results not from type of DOC, but from etiology.

The changed BDNF level after the rTMS course is of particular interest. Literature contains contradictory information: elevated BDNF in serum after rTMS $[27,28]$, and elevated BDNF mRNA in the hippocampus and parietal cortex after the long-term rTMS [29] have been reported. It is concidered that magnetic field during the high-frequency rTMS can stimulate activity of glutamatergic receptors and trigger the synthesis of BDNF, and the low-frequency rTMS, on the contrary, inhibits the BDNF synthesis [30]. Nevertheless, the results of meta-analysis across studies of BDNF level during rTMS are contradictory [30]. The authors note that BDNF level may be also related to etiology of the disorder and patient's age. Therefore, the described biomarker requires further research.

In our study, we found elevated CSF BDNF after rTMS in patients with posttraumatic chronic DOC. Taking into account the protein's neuroprotective properties, this may be due to 
process underlying more favorable recovery that is known for DOC patients after TBI.

The study limitations include the small number of patients, as well as the lack of control group of healthy volunteers for assessment of neurotrophic factor levels in CSF. For more accurate results, especially for group comparison, further study of neurotrophins is required with the inclusion of more participants.

\section{CONCLUSION}

The study of neurotrophic factors in patients with severe brain injury revealed significantly higher serum BDNF, NSE, PDGF, GDNF and NT3 levels in patients with chronic DOC compared to healthy volunteers. The level of BDNF in CSF in patients with chronic DOC was higher in posttraumatic patients, and it significantly increased after the course of high-frequency rTMS. Generally, our results confirm the previous findings about better recovery and more favorable prognosis in patients with $\mathrm{TBI}$ compared to patients with non-traumatic DOC. The data obtained on the neurotrophic factors concentration in the CSF in chronic DOC patients can indirectly indicate that the neuronal plasticity process remains active even in chronic terms of severe brain injuries. This could be considered one of the arguments in favour of recommendations to perform long-term rehabilitation of patients after severe TBI even in the chronic disorder of consciousness setting, since the potential for improvement in this group may persist beyond the first year after trauma.

\section{References}

1. Giacino JT, Ashwal S, Childs N, Cranford R, Jennett B, Katz DI, et al. The minimally conscious state: definition and diagnostic criteria. Neurology. 2002; 58 (3): 349-53. DOI: 10.1212/WNL.58.3.349.

2. Turner-Stokes L, Wade D, Playford D, Kitzinger J, Allanson J, Pundole A, et al. Prolonged disorders of consciousness guidelines. London, 2020.

3. Giacino JT, Katz DI, Schiff ND, Whyte J, Ashman EJ, Ashwal S, et al. Practice guideline update recommendations summary: Disorders of consciousness. Neurology. 2018; 91 (10): 450-60. DOI: 10.1212/WNL.0000000000005926.

4. Piradov MA, Suponeva NA, Vosnyuk IA, Kondratyev AN, Scshegolev AV, Belkin AA, et al. Chronic disorders of consciousness: terminology and diagnostic criteria. The results of the first meeting of the Russian Working Group for Chronic Disorders of Consciousness. Annals of clinical and experimental neurology. 2020; 14 (1): 5-16. DOI: 10.25692/ACEN.2020.1.1. Russian.

5. Thibaut A, Schiff N, Giacino J, Laureys S, Gosseries O. Therapeutic interventions in patients with prolonged disorders of consciousness. The Lancet Neurology. 2019; 18 (6): 600-14. DOI: 10.1016/S1474-4422(19)30031-6.

6. Skaper SD. Neurotrophic factors: An overview. Methods in Molecular Biology. 2018. DOI: 10.1007/978-1-4939-7571-6_1.

7. Ye JH, Houle JD. Treatment of the chronically injured spinal cord with neurotrophic factors can promote axonal regeneration from supraspinal neurons. Experimental Neurology. 1997. DOl: 10.1006/exnr.1996.6353.

8. Chen Q, Zhou L, Shine HD. Expression of neurotrophin-3 promotes axonal plasticity in the acute but not chronic injured spinal cord. Journal of Neurotrauma. 2006. DOI: 10.1089/neu.2006.23.1254

9. Pascual A, Hidalgo-Figueroa M, Gómez-Díaz R, López-Barneo J. GDNF and protection of adult central catecholaminergic neurons. Journal of Molecular Endocrinology. 2011. DOI: 10.1530/JME10-0125

10. Sil S, Periyasamy P, Thangaraj A, Chivero ET, Buch S. PDGF/ PDGFR axis in the neural systems. Molecular Aspects of Medicine. 2018. DOI: 10.1016/..mam.2018.01.006.PMID:29409855.

11. Daubin C, Quentin C, Allouche S, Etard O, Gaillard C, Seguin A, et al. Serum neuron-specific enolase as predictor of outcome in comatose cardiac-arrest survivors: a prospective cohort study. BMC Cardiovasc Disord. 2011; 11: 48. DOI: 10.1186/14712261-11-48

12. Pfeifer R, Borner A, Krack A, Sigusch HH, Surber R, Figulla HR. Outcome after cardiac arrest: predictive values and limitations of the neuroproteins neuron-specific enolase and protein S-100 and the Glasgow Coma Scale. Resuscitation. 2005; 65 (1): 49-55. DOI: 10.1016/j.resuscitation.2004.10.011.

13. Gaede G, Hellweg R, Zimmermann H, Brandt AU, Dorr J, Bellmann-Strobl J, et al. Effects of deep repetitive transcranial magnetic stimulation on brain-derived neurotrophic factor serum concentration in healthy volunteers. Neuropsychobiology. 2014;
69 (2): 112-9. DOI: 10.1159/000358088.

14. Lee JY, Park HJ, Kim JH, Cho BP, Cho SR, Kim SH. Effects of lowand high-frequency repetitive magnetic stimulation on neuronal cell proliferation and growth factor expression: A preliminary report. Neurosci Lett. 2015; 604: 167-72. DOI: 10.1016/j. neulet.2015.07.038.

15. Takahashi T. Monoamines, monoamine metabolites, neuron specific enolase and myelin basic protein concentrations in cerebrospinal fluid of resuscitated patients. Nihon Shinkei Seishin Yakurigaku Zasshi. 1997; 17 (1): 7-16.

16. Suponeva NA, Bakulin IS, Pojdasheva AG, Piradov MA Bezopasnost' transkranial'noj magnitnoj stimuljacii: obzor mezhdunarodnyh rekomendacij i novye dannye. Nervnomyshechnye bolezni. 2017; 7 (2): 21-36.

17. lazeva EG, Legostaeva LA, Zimin AA, Sergeev DV, Domashenko MA, Samorukov VY, et al. A Russian validation study of the Coma Recovery Scale-Revised (CRS-R). Brain Injury. 2019. DOI: 10.1080/02699052.2018.1539248.

18. Legostaeva L, Poydasheva A, lazeva E, Sinitsyn D, Sergeev D, Bakulin I, et al. Stimulation of the angular gyrus improves the level of consciousness. Brain Sciences. 2019; 9 (5). DOI: 10.3390/ brainsci9050103.

19. Karakulova YV, Selyanina NV. Monitoring of neurotrophic factors and cognitive function in patients with traumatic brain injury. Zh Nevrol Psikhiatr im S. S. Korsakova. 2017;117(10):34-37. doi:10.17116/jnevro201711710134-37.

20. Mokhtarzade M, Motl R, Negaresh R, Zimmer P, Khodadoost M, Baker JS, et al. Exercise-induced changes in neurotrophic factors and markers of blood-brain barrier permeability are moderated by weight status in multiple sclerosis. Neuropeptides. 2018. DOI: 10.1016/.npep.2018.05.010.PMID:29880392.

21. King M, Kelly LP, Wallack EM, Hasan SMM, Kirkland MC, Curtis ME, et al. Serum levels of insulin-like growth factor-1 and brain-derived neurotrophic factor as potential recovery biomarkers in stroke. Neurological Research. 2019. DOI: 10.1080/01616412.2018.1564451.

22. Xu L, Zhang Y, Zhang R, Zhang H, Song P, Ma T, et al. Elevated plasma BDNF levels are correlated with NK cell activation in patients with traumatic spinal cord injury. International Immunopharmacology. 2019. DOI: 10.1016/j.intimp.2019.105722.PMID:31255880

23. Sasaki M, Radtke C, Tan AM, Zhao P, Hamada H, Houkin K, et al. BDNF-hypersecreting human mesenchymal stem cells promote functional recovery, axonal sprouting, and protection of corticospinal neurons after spinal cord injury. Journal of Neuroscience. 2009. DOI: 10.1523/JNEUROSCI.2769-09.2009.

24. Ritter C, Miranda AS, Giombelli VR, Tomasi CD, Comim CM, Teixeira AL, et al. Brain-derived neurotrophic factor plasma levels are associated with mortality in critically ill patients even in the absence of brain injury. Critical Care. 2012. DOI: 10.1186/ cc11902.

25. Simon D, Do Nascimento RIM, Filho EMR, Bencke J, 
Regner A. Plasma brain-derived neurotrophic factor levels after severe traumatic brain injury. Brain Injury. 2016. DOI: 10.3109/02699052.2015.1077993.

26. Giacino JT, Katz DI, Schiff ND, Whyte J, Ashman EJ, Ashwal S, et al. Comprehensive systematic review update summary: Disorders of consciousness: Report of the Guideline Development, Dissemination, and Implementation Subcommittee of the American Academy of Neurology; The American Congress of Rehabilitation Medicine; and the National Institute on Disability, Independen. 2018; 91 (10): 461-470. DOI: 10.1016/j.apmr.2018.07.002

27. Yukimasa T, Tamagawa A, Uozumi T, Shinkai K, Ueda N, Tsuji S, et al. High-frequency repetitive transcranial magnetic stimulation improves refractory depression by influencing catecholamine and brain-derived neurotrophic factors. Pharmacopsychiatry. 2006. DOI: 10.1055/s-2006-931542.

\section{Литература}

1. Giacino JT, Ashwal S, Childs N, Cranford R, Jennett B, Katz DI, et al. The minimally conscious state: definition and diagnostic criteria. Neurology. 2002; 58 (3): 349-53. DOI: 10.1212/WNL.58.3.349.

2. Turner-Stokes L, Wade D, Playford D, Kitzinger J, Allanson J, Pundole A, et al. Prolonged disorders of consciousness guidelines. London, 2020.

3. Giacino JT, Katz DI, Schiff ND, Whyte J, Ashman EJ, Ashwal S, et al. Practice guideline update recommendations summary: Disorders of consciousness. Neurology. 2018; 91 (10): 450-60. DOI: 10.1212/WNL.0000000000005926.

4. Пирадов М. А., Супонева Н. А., Вознюк И. А., Кондратьев А. Н., Щёголев А. В., Белкин А. А., и др. Хронические нарушения сознания: терминология и диагностические критерии. Результаты первого заседания Российской рабочей группы по проблемам хронических нарушений сознания. Анналы клинической и экспериментальной неврологии 2020; 14 (1): 5-16. DOI: 10.25692/ACEN.2020.1.1.

5. Thibaut A, Schiff N, Giacino J, Laureys S, Gosseries O. Therapeutic interventions in patients with prolonged disorders of consciousness. The Lancet Neurology. 2019; 18 (6): 600-14. DOI: 10.1016/S1474-4422(19)30031-6.

6. Skaper SD. Neurotrophic factors: An overview. Methods in Molecular Biology. 2018. DOI: 10.1007/978-1-4939-7571-6_1.

7. Ye JH, Houle JD. Treatment of the chronically injured spinal cord with neurotrophic factors can promote axonal regeneration from supraspinal neurons. Experimental Neurology. 1997. DOl: 10.1006/exnr.1996.6353.

8. Chen Q, Zhou L, Shine HD. Expression of neurotrophin-3 promotes axonal plasticity in the acute but not chronic injured spinal cord. Journal of Neurotrauma. 2006. DOI: 10.1089/neu.2006.23.1254.

9. Pascual A, Hidalgo-Figueroa M, Gómez-Díaz R, López-Barneo J. GDNF and protection of adult central catecholaminergic neurons. Journal of Molecular Endocrinology. 2011. DOI: 10.1530/JME10-0125.

10. Sil S, Periyasamy P, Thangaraj A, Chivero ET, Buch S. PDGF/ PDGFR axis in the neural systems. Molecular Aspects of Medicine. 2018. DOI: 10.1016/..mam.2018.01.006.PMID:29409855.

11. Daubin C, Quentin C, Allouche S, Etard O, Gaillard C, Seguin A, et al. Serum neuron-specific enolase as predictor of outcome in comatose cardiac-arrest survivors: a prospective cohort study. BMC Cardiovasc Disord. 2011; 11: 48. DOI: 10.1186/14712261-11-48.

12. Pfeifer R, Borner A, Krack A, Sigusch HH, Surber R, Figulla HR Outcome after cardiac arrest: predictive values and limitations of the neuroproteins neuron-specific enolase and protein S-100 and the Glasgow Coma Scale. Resuscitation. 2005; 65 (1): 49-55. DOI: 10.1016/j.resuscitation.2004.10.011.

13. Gaede G, Hellweg R, Zimmermann H, Brandt AU, Dorr J, Bellmann-Strobl J, et al. Effects of deep repetitive transcranial magnetic stimulation on brain-derived neurotrophic factor serum concentration in healthy volunteers. Neuropsychobiology. 2014; 69 (2): 112-9. DOI: 10.1159/000358088.

14. Lee JY, Park HJ, Kim JH, Cho BP, Cho SR, Kim SH. Effects of low-
28. Zanardini R, Gazzoli A, Ventriglia M, Perez J, Bignotti S, Maria Rossini $\mathrm{P}$, et al. Effect of repetitive transcranial magnetic stimulation on serum brain derived neurotrophic factor in drug resistant depressed patients. Journal of Affective Disorders. 2006. DOI: 10.1016/j.jad.2005.12.029.

29. Müller MB, Toschi N, Kresse AE, Post A, Keck ME. Longterm repetitive transcranial magnetic stimulation increases the expression of brain-derived neurotrophic factor and cholecystokinin mRNA, but not neuropeptide tyrosine mRNA in specific areas of rat brain. Neuropsychopharmacology. 2000. DOI: 10.1016/S0893-133X(00)00099-3.

30. Jiang $\mathrm{B}, \mathrm{He} \mathrm{D}$. Repetitive transcranial magnetic stimulation (rTMS) fails to increase serum brain-derived neurotrophic factor (BDNF). Neurophysiologie Clinique. 2019; 49 (4): 295-300. DOI: 10.1016/j.neucli.2019.05.068. and high-frequency repetitive magnetic stimulation on neuronal cell proliferation and growth factor expression: A preliminary report. Neurosci Lett. 2015; 604: 167-72. DOI: 10.1016/j. neulet.2015.07.038.

15. Takahashi T. Monoamines, monoamine metabolites, neuron specific enolase and myelin basic protein concentrations in cerebrospinal fluid of resuscitated patients. Nihon Shinkei Seishin Yakurigaku Zasshi. 1997; 17 (1): 7-16.

16. Супонева Н. А., Бакулин И. С., Пойдашева А. Г., Пирадов М. А. Безопасность транскраниальной магнитной стимуляции: обзор международных рекомендаций и новые данные. Нервно-мышечные болезни. 2017; 7 (2): 21-36.

17. lazeva EG, Legostaeva LA, Zimin AA, Sergeev DV, Domashenko MA Samorukov VY, et al. A Russian validation study of the Coma Recovery Scale-Revised (CRS-R). Brain Injury. 2019. DOI: 10.1080/02699052.2018.1539248.

18. Legostaeva L, Poydasheva A, lazeva E, Sinitsyn D, Sergeev D, Bakulin I, et al. Stimulation of the angular gyrus improves the level of consciousness. Brain Sciences. 2019; 9 (5). DOI: 10.3390/ brainsci9050103.

19. Каракулова Ю. В., Селянина Н. В. Мониторирование нейротрофических факторов и когнитивных функций у пациентов с черепно-мозговой травмой. Журнал неврологии и психиатрии им. С. С. Корсакова. 2017; 117 (10): 34-37.

20. Mokhtarzade M, Motl R, Negaresh R, Zimmer P, Khodadoost M, Baker JS, et al. Exercise-induced changes in neurotrophic factors and markers of blood-brain barrier permeability are moderated by weight status in multiple sclerosis. Neuropeptides. 2018. DOI: 10.1016/j.npep.2018.05.010.PMID:29880392.

21. King M, Kelly LP, Wallack EM, Hasan SMM, Kirkland MC, Curtis ME, et al. Serum levels of insulin-like growth factor-1 and brain-derived neurotrophic factor as potential recovery biomarkers in stroke. Neurological Research. 2019. DOI: 10.1080/01616412.2018.1564451.

22. Xu L, Zhang Y, Zhang R, Zhang H, Song P, Ma T, et al. Elevated plasma BDNF levels are correlated with NK cell activation in patients with traumatic spinal cord injury. International Immunopharmacology. 2019. DOI: 10.1016/j.intimp.2019.105722.PMID:31255880.

23. Sasaki M, Radtke C, Tan AM, Zhao P, Hamada H, Houkin K, et al. BDNF-hypersecreting human mesenchymal stem cells promote functional recovery, axonal sprouting, and protection of corticospinal neurons after spinal cord injury. Journal of Neuroscience. 2009. DOI: 10.1523/JNEUROSCI.2769-09.2009.

24. Ritter C, Miranda AS, Giombelli VR, Tomasi CD, Comim CM, Teixeira AL, et al. Brain-derived neurotrophic factor plasma levels are associated with mortality in critically ill patients even in the absence of brain injury. Critical Care. 2012. DOI: 10.1186/ cc11902.

25. Simon D, Do Nascimento RIM, Filho EMR, Bencke J, Regner A. Plasma brain-derived neurotrophic factor levels after severe traumatic brain injury. Brain Injury. 2016. DOI: 10.3109/02699052.2015.1077993.

26. Giacino JT, Katz DI, Schiff ND, Whyte J, Ashman EJ, Ashwal S, et 
al. Comprehensive systematic review update summary: Disorders of consciousness: Report of the Guideline Development, Dissemination, and Implementation Subcommittee of the American Academy of Neurology; The American Congress of Rehabilitation Medicine; and the National Institute on Disability, Independen. 2018; 91 (10): 461-470. DOI: 10.1016/j.apmr.2018.07.002

27. Yukimasa T, Tamagawa A, Uozumi T, Shinkai K, Ueda N, Tsuji S, et al. High-frequency repetitive transcranial magnetic stimulation improves refractory depression by influencing catecholamine and brain-derived neurotrophic factors. Pharmacopsychiatry. 2006. DOI: 10.1055/s-2006-931542.

28. Zanardini R, Gazzoli A, Ventriglia M, Perez J, Bignotti S, Maria Rossini $\mathrm{P}$, et al. Effect of repetitive transcranial magnetic stimulation on serum brain derived neurotrophic factor in drug resistant depressed patients. Journal of Affective Disorders. 2006. DOI: 10.1016/j.jad.2005.12.029.

29. Müller MB, Toschi N, Kresse AE, Post A, Keck ME. Longterm repetitive transcranial magnetic stimulation increases the expression of brain-derived neurotrophic factor and cholecystokinin mRNA, but not neuropeptide tyrosine mRNA in specific areas of rat brain. Neuropsychopharmacology. 2000. DOI: 10.1016/S0893-133X(00)00099-3.

30. Jiang $B, H e$ D. Repetitive transcranial magnetic stimulation (rTMS) fails to increase serum brain-derived neurotrophic factor (BDNF). Neurophysiologie Clinique. 2019; 49 (4): 295-300. DOI: 10.1016/j.neucli.2019.05.068. 